\title{
幼児期における助数詞の獲得過程
}

—生物カテゴリーの形成と助数詞付与ルールの獲得——

内田伸子1 1 井むつみ 2

\section{A STUDY ON THE ACQUISITION OF NUMERICAL CLASSIFIERS AMONG YOUNG CHILDREN}

- The development of human/animal categories and generation of the rule of classifiers applying-

Nobuko UCHIDA AND Mutsumi IMAI

This research examined the acquisition of human/animal numerical classifier categories in preschool children. In Experiment 1, using an error detection paradigm, we examined the developmental change of the knowledge 150 children possessed about classifiers. Overall, even the youngest group of children (early 4-year-olds) were aware of the grammatical function of classifiers, but they did not know the semantic criteria for each classifier category until around their late 5 years of age. Experiment 2 examined 604 - and 5-yearolds who had not shown the sensitivity for the semantic rule dividing the hiki (small animal) category and the tou (large animal) category. The results showed that the 5-year-olds only, could spontaneously generate the correct rule and apply it to new items only through hearing adults' use of classifiers. Based on such results, the interplay between the linguistic input, grammar and extra-linguistic cognitive categories in acquisition of classifiers was discussed.

Key words : numerical classifier, preschool children, error detection paradigm, semantic rule, interplay between the linguistic input and cognitive categories.

\section{問 題}

言語獲得において，子どもは認知的意味カテゴリー を先に所有し，それを文法的クラスに対応づけて統語 的知識を獲得していくのか, それとも文法の知識の獲 得が先行し，それから認知的意味カテゴリーを分化， 獲得していくのだろうか。この問題については, Pinker ら (Pinker \& Prince, 1988 ; Pinker, 1991) を中心とし た前者の立場, Gleitman ら (Fisher, Hall \& Gleitman, 1994）を中心とした後者の立場の間で論争されている。

しかしながら，この 2 つの立場のどちらか一方のみ が正しいというよりは, 言語獲得のかなり早い時期か

\footnotetext{
お茶の水女子大学 (Ochanomizu University)

慶應義塾大学 (Keio University)
}

ら両者が双方向的に働いているのではないかと思われ る。たとえば，英語の可算，不可算名詞の区別の獲得 についても個物と物質などの概念的区別が先行すると いう立場(Soja, Carey \& Spelke, 1991) と, 言語的インプッ トから可算か不可算かのクラスをまず学習した後, 徐々にその意味的規則を抽出して自発的にそれを適用 するようになると主張する立場 (Gathercole, 1985) とが ある。子どもは 2 歳前半までにだいたい個物 (object) は可算名詞，物質は不可算名詞という意味的ルールを もち, 個物, 物質の典型事例についてはそのルールを 適応できるが，典型事例でないときには慣習性が重要 なこと (Clark, 1991) を知っている。これは, 子どもの 側の自発的生成と環境からのインプットの双方に頼っ て獲得されていくことを示唆している。 認知的意味カテゴリーが先か, 文法知識が先かとい 
う仮説を検討するためには，助数詞の獲得というのは 非常に興味深い領域である。英語の可算, 不可算名詞 の文法カテゴリーは 2 種しかなく, 典型事例について は個物のように個別化されているものは可算名詞の力 テゴリー，個別化されない物質は不可算名詞というよ うにクラス分けの基準は比較的シンプルである。助数 詞の場合は文法的には可算, 不可算名詞のように名詞 をクラス分けする働きがあるが，そのクラスの数は ずっと多い。たとえば, 日本語の場合, 使用頻度の高 いもの, 頻度の低い特殊なものを併せて70程度の助数 詞が存在する (Downing, 1984）。またクラス分けの基準 も複雑で, 人, 動物, 非生物の区別があり,さらにそ れぞれの領域で細分化される。動物の頭, 匹, 羽など は分類学的基準で区別され, さらに頭, 匹は大きさの 基準でも分けられるなど使い分けの基準が複数にわた ることがある。非生物ではものの形と大きさを基準に した個, 本, 枚, 粒などのクラス, 台のように機能性 を基準にしたクラス，山，杯，箱など計量単位を表わ すクラスなどが混在している (Denny, 1979 ; Matsumoto, 1993)。

他方, 助数詞は名詞と違い閉じたクラス (closed class) の品詞であるから，むやみに新しいクラスはできず, どの助数詞にもあてはまらないような名詞でも, 既存 のクラスのどこかに入れなくてはならない。その結果, 助数詞カテゴリーは意味的な動機はあるが, カテゴ リーの境界が曖昧な放射状 (Lakoff, 1987) のカテゴリー になりがちである。典型事例 (例. 鉛筆 $\rightarrow$ 本) は助数詞ク ラスの意味的基準ははっきりしているが, 非典型事例 (ホームランや電話の通話 $\rightarrow$ 本) は慣習的であり, 大人でも なぜそのクラスに入るのか説明するのが難しい。

このように文法クラスと意味の対応が複雑で非典型 事例が多い助数詞のシステムを子どもはどのように習 得するのであろうか。一般に助数詞の意味システムは 英語の可算, 非可算名詞の区別よりもかなり遅い。た とえば, Matsumoto (1987) は7歳児でもツを本や台の 代わりに一般的に用いたり, 適当なクラスが定まらな いときに用いるという。また，夕イ語の生物領域では， 頻度の高い助数詞クラスでも 3 歳児で $19 \% ， 6$ 歳後半 でも，たかだか $80 \%$ のどもが適用できるにすぎない。 また獲得初期 (4 歳頃まで) には, 頻度の高い一般的な助 数詞をどの名詞にも適用する誤用が顕著であり, 加齢 に伴い特定の助数詞クラスの意味的基準を使ったため の般用 (overextention) が多く見られる (Carpenter, 1990)。これらの知見を踏まえると, 子どもは, まず, ものを数えるときには数字のあとに何かを付けなくて
はならないらしいことに気づくが, 意味的基準を抽出 して新しい事例に正しくプロダクティヴに適用できる ようになるまでにはかなり時間がかかるものと予測さ れる。夕イ語と同様, 日本語でも助数詞の正しい運用 までにはいくつかの段階を経ると考えられるが, それ を明確に示すデータはなく，この点を明らかにするこ とは, 言語心理学的視点から見て, 重要な課題となる。 本研究では, 生物カテゴリーを対象にして幼児がど のように日本語の助数詞の意味的基準を獲得していく かについて以下の 4 点について明らかにする。第 1 に, 夕イ語と同様に, 日本語でも典型事例の助数詞の獲得 が早いであろう, 第 2 に, 言語領域以外の一般的な認 知領域での生物学の知識獲得 (稲垣, 1995 ; Inagaki \& Hatano, 1987）と平行して, 人の助数詞が匹・頭・羽に先 行して獲得されるであろう，という予測を検討する。 第 3 に, 自発的に生成された意味ルールの般用が見ら れるか, 第 4 に, 何歳頃から意味的基準について自覚 化ができるようになるかについて検討する。

\section{実 験 1}

\section{目的}

ラベル獲得の認知の関係を明らかにするため, 上記 の 2 つの予想と 2 つ問題点について検討することを 目的にする。

\section{方法}

実験計画 年料 $(5) \times$ 助数詞のタイプ(4)×典型性(4)の 3 要因計画, 第 1 要因は群間, 第 2 , 第 3 要因は群内 要因である。

被験者 4 歳前半 (m; 4 歳 2 か月, $\mathrm{r} ; 4: 0 \sim 4: 5), 4$ 歳後 半 ( $m ; 4$ 歳 8 か月, $r ; 4: 6 \sim 4: 11), 5$ 歳前半 ( $m ; 5$ 歳 3 か月, $r ; 5: 0 \sim 5: 5), 5$ 歳後半 ( $m ; 5$ 歳 8 か月, $r ; 5: 6 \sim 5: 11), 6$ 歳 前半 ( $\mathrm{m} ; 6$ 歳 2 加, $\mathrm{r} ; 6: 0 \sim 6: 5)$ の 5 年齢段階, 男女 半々，各30名からなる計150名を対象にした。

なお規準デー夕を得るため大学生20名を対象にして， (1)大人が用いる助数詞の種類, (2)対象刺激の典型性に ついて，馴染み深いを 1 点，馴染みがないを 5 点とす る 5 段階評定の 2 つの質問紙調査を実施した。

刺激材料 生物の代表的なカテゴリー4 種を選択し, 各カテゴリーに属する生き物から，成人被験者 20 名に よる評定結果に基づき，85\%以上が同一助数詞を選択 した対象であること, かつ, 典型性の 4 水準で分類し

\footnotetext{
33 歳後半児も対象にしたが, この実験パラダイムを理解でき ず, 教示通りの行動ができなかったので, 本研究では 3 歳後半 児のデータは省いて分析した。
} 
た対象であることの 2 点を規準にして，刺激材料 （TABLE 1）を作成した。

\section{TABLE 1 実験 1 の実験材料}

\begin{tabular}{|c|c|c|c|c|}
\hline $\begin{array}{l}\text { 典型性 } \\
\text { 助夕 } \\
\text { 数 } \\
\text { 詞 } f\end{array}$ & 典型 & 非典型 & $\begin{array}{l}\text { 知覚的心類似 } \\
\text { 別力テコリリー }\end{array}$ & $\begin{array}{l}\text { 非生物 } \\
\text { 非楼似 } \\
\text { 別力テコリリー }\end{array}$ \\
\hline$\pi$ & 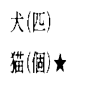 & 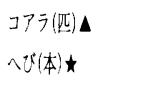 & 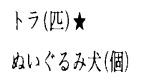 & $\begin{array}{l}\text { 石(㐳) } \\
\text { コッナ個) }\end{array}$ \\
\hline 頙 & $\begin{array}{l}\text { 象(頙) } \\
\text { 馬(本)` }\end{array}$ & 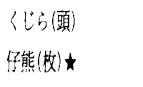 & $\begin{array}{l}\text { 熊のぬいくろみ(頙)れ } \\
\text { 洗い熊(匹) }\end{array}$ & 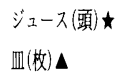 \\
\hline 人 & 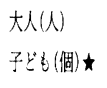 & $\begin{array}{l}\text { 小以(N) } \\
\text { ウルトラマン(本)ネ }\end{array}$ & $\begin{array}{l}\text { チンパンジー(人) } \\
\text { ロホホット(台) }\end{array}$ & 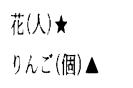 \\
\hline 羽 & 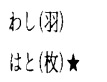 & $\begin{array}{l}\text { だちょう(羽) } \\
\text { ペンギン(個)ネ }\end{array}$ & 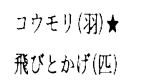 & $\begin{array}{l}\text { ビスケット(羽) } \\
\text { スナーン(本)ム }\end{array}$ \\
\hline
\end{tabular}

【: 数え飛代しによる数え違い $\star:$ 算助数詞

なお，典型性の水準は，「典型」は1.2以下，「非典型」 は4.0以上の評点を得たもの・「所属カテゴリーは別で も見かけの似ている生き物」・「非生物」の 4 つである。 手続 次の 2 つセッションからなる。

セッション $\mathrm{I}^{4}$ : 数える場面への導入であり自発的 産出を見るための (1) 導入課題と (2) 産出課題 (誤り検 出パラダイム(error detection paradigm)による) を課した。

（1）導入課題；描かれた事物や身近な事物を提示して 数えてもらう。

（2）産出課題；恐竜の赤ん坊のぬいぐるみ（ジョジョ） に数え方を教えたいので手伝ってもらうという場面を 設定し, 実験者, 恐竜, 子どもの会話で進めていく。 恐竜の台詞は実験者が恐竜に指を入れて, その口を開 閉させながらトーンの高い声色を使った。

セッションII：(1) 練習課題；「ジョジョちゃんは まだ赤ちゃんだからうまくしゃべれないの。間違えて たら教えてあげて」という教示で, 数え違い(ミッキー マウス 2 人 $\rightarrow 3$ 人) と助数詞違い（甲虫 3 匹 $\rightarrow 3$ 本）の 2 問 を, 被験者に修正してもらい, 修正の理由を恐竜に向 かって説明してもらう。(2) 修正課題; TABLE 1 の刺 激 (それぞれ2〜5 個) が線画で描かれたB5 版の絵カード

4 セッションI の刺激は, 線画としては, 犬, 人間, 自動車, 䳕, リス, ライオン, グレートデンの 7 項目, 実物では, 画用 紙, 絵本, 鉛筆, 消しゴム, スプーン, ロボット, 皿, 小人の 8 項目からなる。
を置き, 計画に従って, 恐竜が, 数え違い, 助数詞違 い, 正答からなる対象を数えあげるのを聞いて，子ど もが誤りを指摘し (再認レベル), 修正して（再生レベル）, なぜ間違えているかについての理由づけを言う手続を 繰り返した。課題（匹・頭・人・羽）の提示順はランダム で被験者によりカウンターバランスをとった。

分析方法 評定基準は以下の通りである。(1) 再 認；合否ともに合致した場合に 1 点を与えた。(2) 再 生；修正すべき項目に適切な助数詞で修正したら 1 点, 間違えて修正したら 0 点, 修正すべきでないのに修正 したら 0 点という基準で得点を与えた。(3) 理由づ け；(1)妥当な理由づけ（例. 頭:「大きな動物だから」）は 2 点, (2)正愦反応とは一貫していてもカテゴリーを間違 えていたら（例. コウモリを羽をつけて数えて「鳥だから」） 1 点, (3)慣用を基準にした答え(例. お母さんがそう数えてい るから）が 1 点，他は 0 点として得点化した。

\section{結果}

(1) 再認得点と修正得点の比較 助数詞の全体的な獲 得様態を見るため, 助数詞の使用の正誤を判断できる かどうかの再認の総得点 (32 点満点) と誤っていると判 断した場合に正しく修正できたかどうかの総得点 $(32$ 点満点）の年秢群別平均を FIGURE 1 に示した。これに ついて, 年齢(5)×テストタイプ (再認・修正) の 2 要因複 合型分散分析を行った結果, 年齢の主効果 $(\mathrm{F}(4,145)=$ $1749.42, \mathrm{p}<.0001)$ とテストタイプの主効果 $(\mathrm{F}(1,145)=1895$. $05, \mathrm{p}<.0001)$, 並びに, 年齢 $\times$ テストタイプの交互作用 $(\mathrm{F}(4,145)=9.24, \mathrm{p}<.001)$ のいずれも $1 \%$ 水準で有意で あった。Tukey 法による対間分析を行った結果, 6 歳 前半, 5 歳後半》 5 歳前半, 4 歳後半》 4 歳前半の間 5 が $1 \%$ 水準で有意であることから，4歳前半では助数

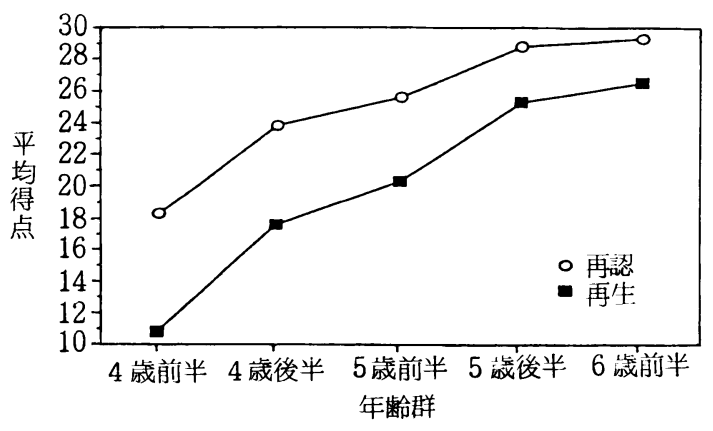

FIGURE 1 正誤判断得点と修正得点の比較 (最大値：32)

5 対間比較の有意水準は, 〉が $\mathrm{p}\langle .05$,》が $\mathrm{p}<.01$ を示している。 
詞の誤りに気づいたとしても，正しい助数詞を想起し て使うことは難しいが， 5 歳後半頃からかなり正確に 想起できるようになることを示している。

付与される助数詞の種類を見ると, ツ・コが 2 歳台 から付けられ始めるという知見（仲, 1994）と併せると, 初期にツ・コが使われる経験を踏まえて，4歳後半頃 から適切な助数詞が付与され始めるようになり，5歳 後半すぎには，かなり適切な使い分けが可能になると いう傾向がうかがわれた。なお，再認·修正得点の各々 については, 評価基準に従って正誤反応を得点化し, 年齢(5)×タイプ(4)×典型性(4)の複合型 3 要因分散分析 を行い, 各主効果, 交互作用が有意であるとの結果を 得たので，仮説検証に関わる下位分析の結果を以下に 報告する。

（2）典型性の要因；修正得点について典型性別に年齢 毎の平均得点 (匹〜羽の合計点, 8 点満点) を FIGURE 2 に示 す。これについて, 年齢(5) ×典型性(4)の 2 要因複合型 分散分析を行った結果, 年齢の主効果 $(\mathrm{F}(4,145)=65.18, \mathrm{p}$ く.0001）と典型性の主効果 $(\mathrm{F}(3,435)=44.08, \mathrm{p}<.0001)$ ，なら びに年齢 $\times$ 典型性の交互作用 $(F(12,435)=3.90, p<.0001)$ の いずれも有意であった。

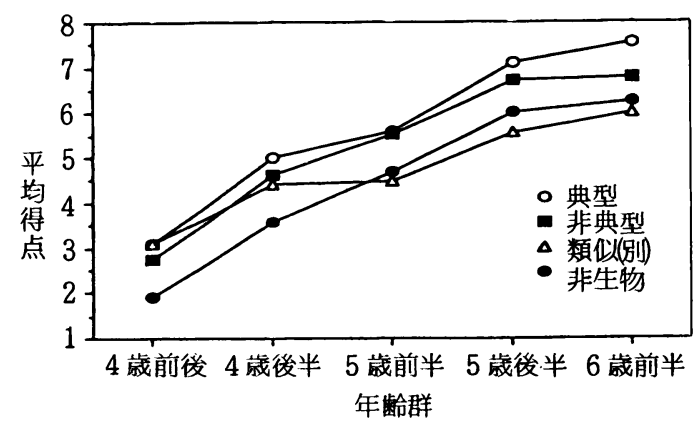

FIGURE 2 典型性別修正得点(最大値：8)

Tukey 法を用いて対間比較を行うと, 典型性要因に ついては, 典型》非典型, 非生物〉別のカテゴリーの 順に獲得されていくことが示された。典型的なものほ どよく習得され, 別カテゴリーに属していても見かけ が似ている対象については誤りが多いことが示された。

典型的な項目について年齢比較を行うと，6歳前半, 5 歳後半> 5 歳前半, 4 歳後半> 4 歳前半となり, 5 歳 後半過ぎには典型的な対象なら助数詞はかなりよく習 得されていることが明らかになった。これは第1の予 想を支持している。

(3) 助数詞のタイプ 助数詞のタイプ別に年齢毎の修 正得点の平均点 (無生物を除く, 典型〜カテゴリー外の合計点,
6 点満点)を FIGURE 3 に示す。これについて年齢(5) ×助 数詞夕イプ(4)の 2 要因複合型分散分析を行うと, 年齢 の主効果 $(\mathrm{F}(4,145)=57.780, \mathrm{p}<.0001)$, 夕イプの主効果 $(\mathrm{F}(3,435)=44.48, \mathrm{p}<.0001)$, 年齢 $\times$ タイプの交互作用

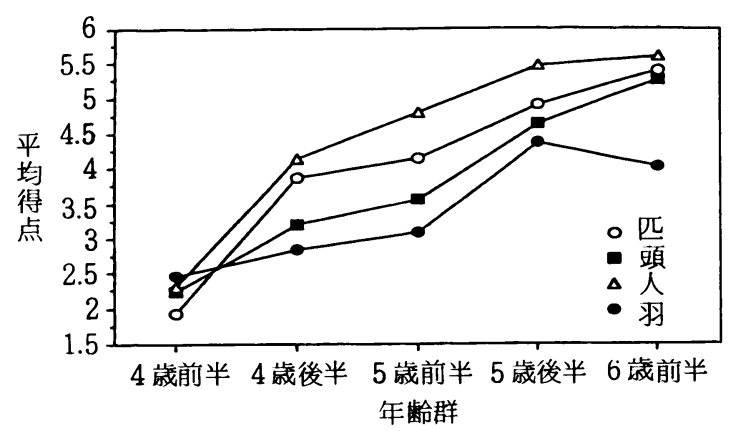

FIGURE 3 助数詞タイプ別修正得点(最大值：6)

$(\mathrm{F}(12,435)=6.24, \mathrm{p}<.0001)$ のいずれもが有意であった。

Tukey 法により対間比較を行うと，人〉匹>頭〉羽の 間が有意であり, 人が最も獲得しやすく, 次に匹, 頭 と続き，羽が遅れることが示唆された。これは第 2 の 予想を支持している。

タイプによって獲得年齢が異なるかどうか見ると, 人, 匹については 5 歳前半》 4 歳後半》 4 歳前半の間が 有意であり, 頭においては, 5 歳後半》 5 歳前半, 4 歳 後半> 4 歳前半の間が有意であった。羽は 5 歳後半> 6 歳前半》5 歳前半, 4 歳後半> 4 歳前半の間が有意で あった。なお， 6 歳前半が 5 歳後半よりも得点が低く なったのは, 大型の動物は頭で数えることに気づき始 めたことによるものと考えられる。

このように推測する根拠は次の事実に基づく。すな わち， 5 歳児はセッションI でライオンに頭を用いた のは30名中 5 名で, この全員がセッションIIで駝鳥を 頭と数えた。6 歳児になると大型動物に対し頭で数え る子どもは11名と増加している。頭を用いた11名のう ち10名はセッションII の修正課題で駝鳥に対して頭を つけて数え, 修正の理由も「大きいから」と答える子 どもが多かった。このことは, タイ語の助数詞につい ての知見と同様に，大きさという基準によって頭を用 い始めるに伴い，その共通特性をもった対象に過度の 般用をしたことを示唆している。

(4) 理由つけけ 助数詞タイプ別に理由づけの得点を算 出 (8 点満点) し, その平均を FIGURE 4 に示す。これに ついて年齢(5)×助数詞夕イプ(4)の 2 要因複合型分散分 析を行った結果, 年齢の主効果 $(\mathrm{F}(1,145)=115.45, \mathrm{p}<$ $.0001)$, タイプの主効果 $(\mathrm{F}(3,435)=21.71, \mathrm{p}<.0001)$, 年齢 $\times$ 
タイプの交互作用 $(\mathrm{F}(12,435)=6.10, \mathrm{p}<.001)$ のいずれもが 有意であった。同様に人・匹・頭毎に対間比較を行う と, 人と匹については, 6 歳前半 $=5$ 歳後半》 5 歳前 半 $=4$ 歳後半》 4 歳前半となり, 獲得度の低い羽は 6 歳後半 $=5$ 歳後半》 5 歳前半 $=4$ 歳後半> 4 歳前半の 間が差が有意であった。理由づけは 4 歳後半ごろから 可能になり始めるが，意味的基準についてシステマ ティックな理由づけができるようになるのは 5 歳後半 過ぎのことであることが確認された。また，個人別に 得点の分散を見ると, 理由づけができる場合はどれに ついてもでき，できない場合はどれについてもできな いことがわかった。助数詞の獲得の程度と理由づけの 可否が対応していないということは, 助数詞の知識だ けでなく, 説明技能やモニタ一機能や評価など他の認 知機能の発達とも関連している (内田, 1990) ことを示唆 している。

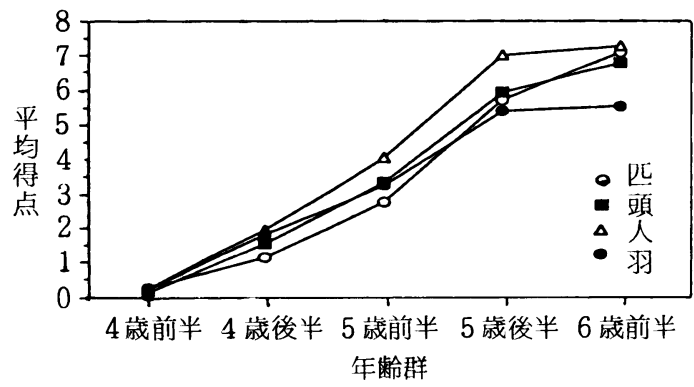

FIGURE 4 理由づけ得点(最大值：8)

理由ブけのプロトコル例を TABLE 2 に示したが，こ れから推測されるように，子どもは慣用を基準にする こともあるが，多くは助数詞付与ルールを自分で生成 して，それを一貫して付与していることが示唆される。 以上から，(1)典型的なものほど早く，また身近なた めに，見たり数えたりする経験があると想定されるも のから先に習得されること，(2)助数詞は，人間に関す る知識や知覚的特徵をべースにして人 $\rightarrow$ 匹頭 $\rightarrow$ 羽の 順に獲得されていくこと, (3)助数詞運用において過度 の般用が見られること，(4)助数詞は幼児期を通じて 徐々に獲得され，4歳後半〜 5 歳前半にかけて, 数え るときは何か付けるらしいという意識が見られるよう になり, 幼児期後期 (5 歳後半) に助数詞付与のルールを 生成して，それを体系的に対象にあてはめ，また問わ れればルール付与の基準も説明できるようになること が明らかにされた。

これを通して, 生物カテゴリーが分化することと助 数詞付与のルールの抽出は相互に関連しながら次第に
TABLE 2 修正の理由づけのプロトコル例

\begin{tabular}{|c|c|c|}
\hline 項目 & I.K. $(6: 1)$ 猩正: 理由うけ & I.S. $(5: 10)$ 位正: 理由ゔ \\
\hline 猫(個) & 匹:動物だ加 & 匹:動物沈加ら \\
\hline 蛇(本) & 匹:注蟖㙂加ら & 匹：これも動物なん芯よ \\
\hline 虎(元) & 頭：大きいから & (間違いに気つかかない) \\
\hline 石(元) & 個:固心加ら & 個:固くて小さいものだ加ら \\
\hline 馬(本) & 頭:大きいから & 匹:動物だ加ら \\
\hline 鯨(頍) & 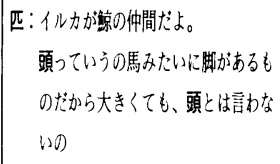 & 匹: 動物沈加 \\
\hline 仔熊(枚) & 匹：小さい加ら。親熊なら頭 & 匹:動物だから \\
\hline 熊又イタルミ(頍) & 個：ヌイグルミ物でしょう & 匹:生きていないけと動物泇ら \\
\hline 㼛ジュース(頭) & $\begin{array}{c}\text { 杯：前、ぱくジュースのことは杯って数 } \\
\text { えたの見たことあるもん }\end{array}$ & 本:長加员 \\
\hline 子ど匕(個) & 人:ヒトだ加ら & 人:ヒトの仲間、人間の仲間芯から \\
\hline ウルトラマン(本) & $\begin{array}{c}\text { 人:間が変身したものだし、ウルトラ } \\
\text { 星加ら来た人みたいなっものだから }\end{array}$ & 人：人が変身したものなんたよ \\
\hline チンバンジー(人) & 匹:動物だ加ら & 匹：人間じャ支い。動物でよ! \\
\hline 花(人) & 本:長和战 & 本：㙊いし、鈶筆みたいでしよ \\
\hline 䲴(敉) & 羽:鳥地加 & 羽：島芯よ。鳥の仲間なんたよ \\
\hline 㳦鳥(羽) & $\begin{array}{l}\text { 頭:配鳥住鳥去んだけど，鳥で大きい } \\
\text { 加ら }\end{array}$ & の(合っているよ」と誩引 \\
\hline ペンギン(個) & 匹:鳥で空は飛べなから & $\begin{aligned} \text { 羽: ペンギンも鳥, 水の中を永を使って } \\
\text { 泳いでんの }\end{aligned}$ \\
\hline コウモリ(羽) & 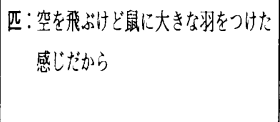 & 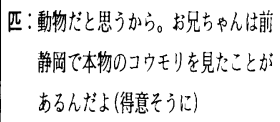 \\
\hline ビスケット(羽) & 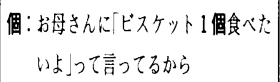 & 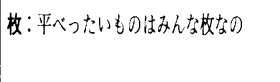 \\
\hline
\end{tabular}

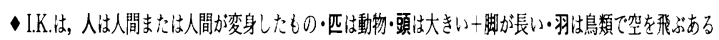

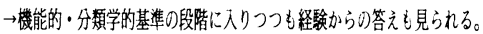

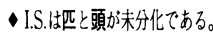

はっきりしていくものであることが示唆された。しか し，どう関連するのかは不明である。そこで，どのよ うなプロセスがルールの生成を促進するのかについて 検討することにした。

この目的のために，匹と頭の分化を取り上げること にした。実験 1 の理由づけを見ると，大きさを基準に して数え分けていることが示唆された。また鯨を頭と 数えたときに「イルカが鯨の仲間だよ。頭っていうの 馬みたいに脚があるものだから大きくても，頭とは言 わないの」(I.K. $6:$ 1) というようなプロトコルを見る と，助数詞付与の基準は子どもが自分で生成していく ものであることを示唆している。これらのことは本当 であろうか。もしそうなら，ある種の基準についての 知識の獲得が助数詞付与を可能にしているものと考え 
られる。この点を実験 2 で確かめることにした。

\section{実 験 2}

目的；次の 2 つ仮説を検証することを目的とする。 第 1 に，複数の事例を同一助数詞を付けて数えると いう経験があれば，基準を明示的に教えられなくても 助数詞付与ルールが抽出されるであろう。

第 2 に, 助数詞の付与範囲を定めるためには知覚的 次元への着目が不可欠であろう。

\section{方法}

実験計画 2 年齢（4 歳児·5 歳児） $\times 3$ 条件（基準明示. 模做再生·統制) 22 要因計画。第 1 , 第 2 要因とも独立 である。

被験者 匹と頭の区別がつかない 4 歳児 $(\mathrm{m} ; 4$ 歳 11 朋, $\mathrm{r} ; 4: 7 \sim 5: 3) \cdot 5$ 歳児 ( $\mathrm{m} ; 5$ 歳 9 か月, $\mathrm{r} ; 5: 7 \sim 6: 2)$ 60名 ${ }^{6}$ 。男女半々，WPPSI の下位検査「文章」で測定 した認知能力の程度が等質な 1 群 10 名からなる 2 年齢 3 群に分け，呼び分け基準を明示する明示群，正しい ラベルを模倣させるラベル群，自発的に数えさせる統 制群に割り当てた。

手続；プリテスト $\rightarrow$ 訓練（2 種の訓練条件・訓練無し）－ ポストテスト $\rightarrow$ 遅延（1 週間後）ポストテストの順に 実施した。その内容は次の通りである。

(1) プリテスト「この子はジョジョちゃん。まだ数 え方がよくわかりません。これから数え方を教えてあ げようと思うんだけど，手伝ってくれる？」と絵カー ドの動物を数えさせ，分化していない子どものみ(2) に進む。（2）訓練 明示群は“大きさ”に着目させ る。練習項目は(1)ダックスフント・グレートデン, (2) 猫・虎，(3)仔熊・親熊 (下線項目は頭) であり，それぞれ の対を順に対比して見せ，数えさせる。匹と頭が分化 していないことを確認した後，下線項目を指して「○ ○ちゃんは匹っていったけど，頭って数えるの。数え

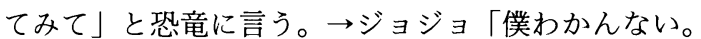

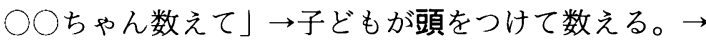

${ }^{6} 5$ 歳クラスの匹と頭が分化している約 3 分の 1 の子どもを抜 かして, 分化していない子どもを, 男女半々, 知能值のマッチ ングによって群分けを行ったため, 200名近い子どもから抽出 したことになる。

[ラベル群］は，正しい助数詞を付けるのを聞いて、繰り返す だけである。これは，いわば「母親方略」を模して設定した条 件である。一般に母親が子どもに数えて聞かせるときには, 子 どもの水準に合わせるのが普通である。たとえ, 子どもの水準 よりも高い水準の助数詞を付けて数えることがあっても, 水準 を変えた自覚はなく, なぜその助数詞を用いたのかについてに 説明することはしない（仲，1994）。
ジョジョ「どうしてこっち(非下線項目)は匹なのに,こっ

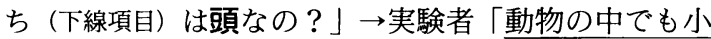
さいのは匹でいいけど，大きいのは匹ではなくて，1

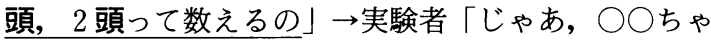

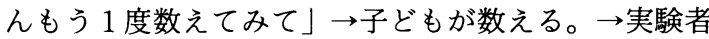
「どうしてこっちは頭なの？」と問い，説明させ，基 準8を理解したかどうかを確認する。

ラベル群は正しい助数詞をつけて数えて見せる。 $\rightarrow$ 練習(1)から順に対比して提示し，子どもに数えさせて， どちらも匹となることを確認した後,「でも,こっち(下 線項目) は頭って数えるの。数えてみて。」と子どもに数

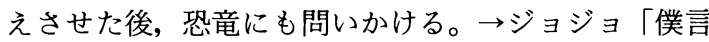

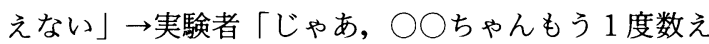
てみて」と教えさせる。

統制群は，練習 3 問を対比して提示し，数えさせる だけである。全員どの対象にも匹をつけて数えた。

(3) ポストテスト 手続 絵カードの動物を数えさ せて箱に入れさせる。子どもが匹と頭と数え分けたら 2 つの箱のそれぞれに目印として絵カードを立てかけ る。，実験者「こちらは匹のおうち，こちらは頭のお うち，さあこれはどっちのお家に入るかな？」と子ど もに数えさせ，絵カードを箱に分けて入れさせる。

刺激材料 既知動物と末知動物 (想像上の動物) の線画 B 6 版の絵カードを用いた（TABle 3 •Figure 5)。各テス トでの材料の提示順はランダムである。

TABLE 3 実験 2 の実験材料

\begin{tabular}{|c|c|}
\hline テスト & 項目 \\
\hline プレテスト & (1)[小]ダックスフント・猫・仔熊 \\
\hline 大小 3 項目 & (2)[大]グレイハウンド・虎・親熊 \\
\hline ポストテスト & (1)匹：甲虫・多ックスフント・猫・仔犬・コアラ \\
\hline \multirow[t]{2}{*}{3 種 5 項目 } & (2)頭；馬・象・ライオン・虎・鯨 \\
\hline & (3)人；子ども・小人、個；縫いぐるみ、羽；䉆・鳵 \\
\hline 遅延テスト & (1)匹；仔猿・鼠・仔熊・金魚 \\
\hline ポストテスト事例 & (2)頭：白熊・象 \\
\hline + 3 種 6 項目 & (3)羽；キューイ・䲴・駝鳥・ニワトリ \\
\hline 架空の生き物 & (1)[小]小鯉怪獣・山羊獣 \\
\hline \multirow[t]{2}{*}{8 項目 } & (2)[大]立位恐竜・恐竜・ドラゴン・ \\
\hline & 4 本足獣・鲤怪獣・ライオン獣 \\
\hline
\end{tabular}

評定基準 (1)反応：実験 1 に準じて得点化した。(2) 駝鳥の過般化；駝鳥を [頭］と数え, その理由は「大

8 本研究では扱っていないが, 対象によっては, 形状だけでなく 機能的な類似性も助数詞の付与ルール生成の基準となる場合 もある。 


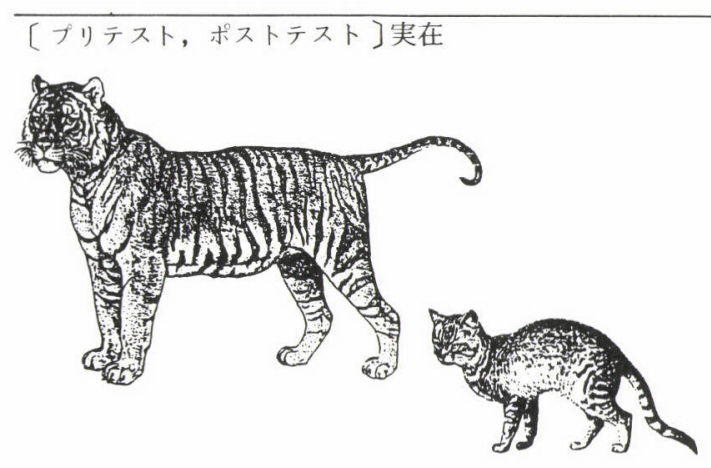

[転移課題]架空
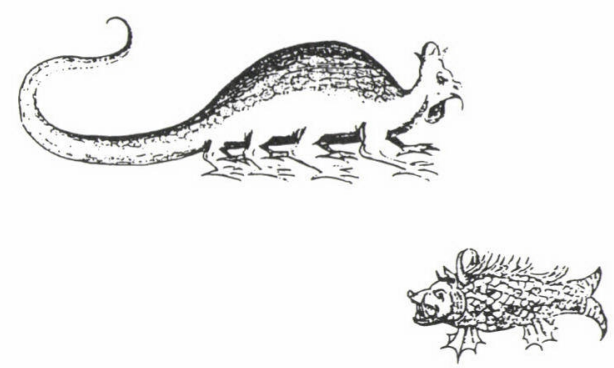

FIGURE 5 実験 2 の材料例

きいから」と答えた人数。(3)理由づけの多様性；「大 きいから」「小さいから」という訓練で実験者が用いた ことば以外の表現がどれくらい使われているかを判定 した。

\section{結果}

（1）訓練直後・遅延テストの結果 条件毎の得点につ いて；FIGURE 6 に示した頭の得点 (10 点満点) につい

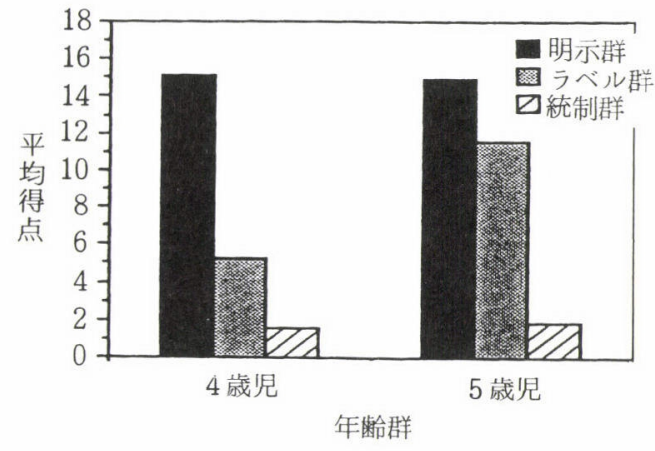

FigURE 7 転移課題の得点(最大值：16)

て, 条件 (明示・ラベル・統制群) $\times$ 年齢 $\times$ テスト時期 (直 後・遅延）の繰り返しのある 3 要因分散分析を行い, さ らに Tukey 法による下位検定を行った。

その結果, 条件の主効果 $(\mathrm{F}(2,54)=217.10, \mathrm{p}<.01)$, 年齢 の主効果 $(F(1,54)=18.75, p<.01)$ とも有意であり，5歳児 の明示群とラベル群, 4 歳児明示群は他の条件に比べ, 得点が高いことが見いだされた。

また, 条件 $\times$ 年齢の交互作用 $(\mathrm{F}(2,54)=13.55, \mathrm{p}<.01)$ も有 意であり，年齢によって条件の成績が異なることがわ かった。またテスト時期の主効果も有意となり（F(1, $54)=4.48, p(05)$, 遅延テストの方が得点が高くなった。

(2) 転移課題の結果 評定基準に従って得点化した (16 点満点) 結果 (FIGURE 7 参照) について, 条件(3) × 年歯（5 歳・4 歳）の 2 要因の分散分析を行った結果，条 件の主効果 $(\mathrm{F}(2,54)=109.19, \mathrm{p}<.01)$, 年歯の主効果 $(\mathrm{F}(1$, $54)=8.76, p<.01)$, 条件 $\times$ 年齢の交互作用 $(\mathrm{F}(2,54)=8.40, \mathrm{p}$ 〈.01)のいずれも有意であった。下位検定の結果，5歳 児明示群・ラベル群, 4 歳児明示群が他の群よりも成

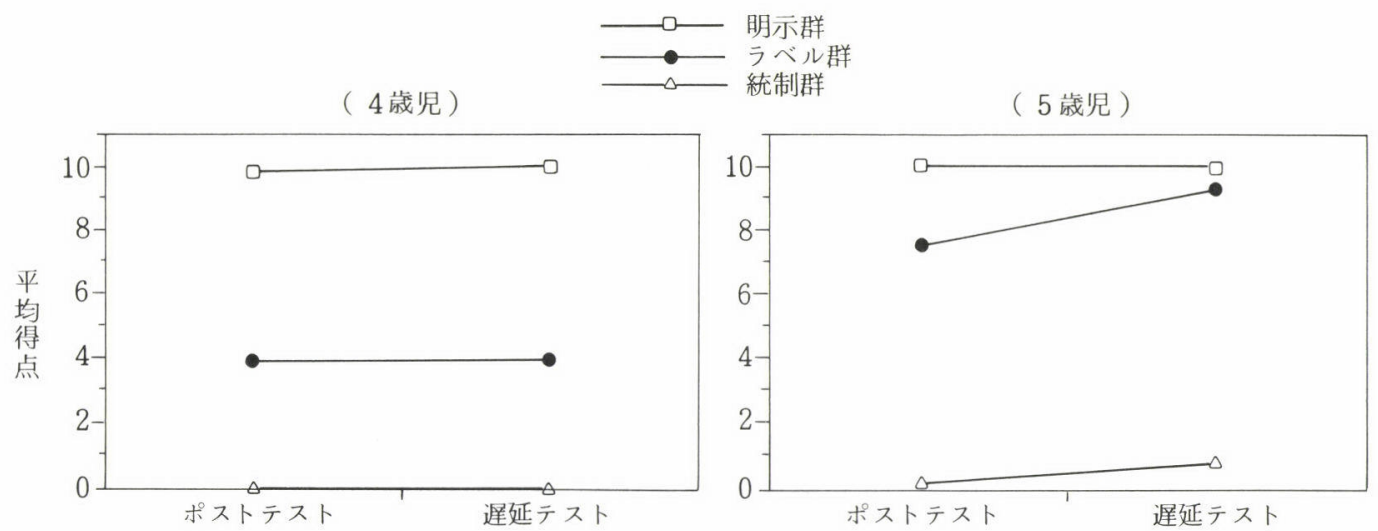

FIGURE 6 [頭]課題の得点(最大值：10) 
績が高かった。

以上から，5歳児においては，ラベルの模倣再生を 通して助数詞付与ルールを自発的に抽出できるが， 4 歳児は不可能であり，仮説 1 は支持された。

（3）駝鳥への頭の般用 頭を駝鳥にもあてはめた人数 は明示群では, 5 歳児 9 名, 4 歳児 10 名, ラベル群で は, 5 歳児 8 名, 4 歳児 2 名であり, 統制群はどちら の年齢群も 0 名であった。明示群ではほとんどの子ど もが般用した。しかし，ラペル群では 5 歳児のみが般 用している。これは 5 歳児がルールを意識化し始めた ことを示唆している。一方，4歳児は基準について自 覚的でないため，般用は起こらなかったのであろう。

（4）理由づけの多様性 訓練時に実験者が用いた「大 きいから」という表現以外の表現を用いた子どもはラ ベル群 5 歳児, 4 歳児とも 7 名ずついたが, 他の群に はいなかった。TABLE 4に示したラベル群の理由づけ のプロトコルを見ると，5歳児は大きさに言及してい るが，4歳児でたまたま目についた特徵をあげる場合 がほとんどであった。これは，5歳児は大きさという 知覚的次元に着目しており，その着目次元を明示され なくても自発的にルールを抽出することができること を示唆している。このことは大きさという知覚的次元 への注目が前提になって助数詞の使い分けが決まるで あろうとの仮説 2 を支持している。

\section{TABLE 4 ラベル群の理由づけのプロトコル例}

\begin{tabular}{ll}
\hline \multicolumn{1}{c}{5 歳児群 } & \multicolumn{1}{c}{4 歳児群 } \\
\hline でっかいから* & お目々が黒いから \\
角が伸びて鼻が伸びてて, でっかい & お顔が似ているから \\
尻尾が長くて, でっかい & 2 頭だから \\
大きくて幅が大きいから & 象だから \\
大きい動物だからだと思う & お馬だから \\
背が高いから & 動物だから \\
首が長いし、背が高くて大きいから & 覚えてたから \\
おっきめだから & おっきい方が1頭, 2 頭だよ \\
大きくて強そうだから & おっきいもん \\
\hline
\end{tabular}

* 太字は大きさの次元に言及したものを示す。

\section{総括的討論}

（1）実験結果 実験 1 では，生物の領域を対象にして， 助数詞がどのように獲得されていくかを取り上げた。 まず，身近な生き物，とくに人間についての助数詞か ら獲得されていく。幼児は人間についての知識をある 程度豊かにもっており, その知識から未知の事象を類 推していくものだという知見（稲垣, 1995 ; Inagaki \&
Hatano, 1987）を踏まえると，子どもがよく知っている ものからラベルを獲得していくことが示唆される。

助数詞の夕イプによって，獲得される時期は異なる が, 人や匹は 4 歳後半から獲得され， 5 歳台ではかな り付与することができるようになる。同一クラスの中 では典型性の高い対象ほど早く獲得されることが確認 された。頭や羽などは，5歳後半過ぎから分化し始め, この分化の時期には, 夕イ語の助数詞獲得や言語獲得 初期のような般用が起こることも明らかになった。理 由づけを見ると, 自分なりの基準を使って, 適用範囲 を決めていることがうかがわれた。

実験 1 では, 助数詞付与ルールをどのように獲得す るかを見たが，子どもは頭を匹から分化させる場合に 〈大きさ〉という知覚的類似性を基準に助数詞付与 ルールを自発的に生成し，適用範囲を決めていくこと が明らかになった。もちろん, 子どもがルールを自発 的に生成しているということは，そのルールが慣用と は異なる可能性も多いと考えられる。助数詞の適用範 囲が子どもによって, ときに大人であっても, 食い違 うことがあるのはこのためであろう。

実験 2 のラベル群においては，4 歳児はある助数詞 を当てはめるのには何らかの基準がありそうだという 予想はあっても, 正しくその基準に到達できなかった のに対して，5歳児はルールを自発的に正しく生成す ることができた。すなわち, 頭と数えるカテゴリーの 範囲の基準となるのは大きさだということを類推し， 見たこともない架空の生き物に対してもあてはめるこ とができたのである。この事実から，助数詞が獲得さ れる過程が推測できる。

（2）意味が先か, 文法クラスが先か 先行研究(Carpenter, 1991）と一致して, 本研究での生物領域での助数詞 の獲得は，まず，ものを数えるときに名詞の後に助数 詞をつけなければならない，という文法規則に先に気 づくが，それぞれの意味基準についての自発的ルール の生成, 適用には時間がかかる, というパターンであっ た。このパターンは言語の他の領域, 例えば, 動詞の 使役構文 (causatives) にも見られる (Bowerman, 1982)。 ただ，この場合には，子どもは最初は大人のインプッ トどおりの正しい構文を発話し, 後になってルールに 気づき始めるとルールの過度の般用による誤用をする ようになる, という U 型の発達パターンを示すが, 助 数詞の場合は, 必ずしも, 慣用法どおりの正しい使用 が最初に見られるとは限らない。これは, 助数詞のク ラスが多すぎるのと, クラス分けの基準がわかりにく いためではないだろうか。 
以上のように, 現象から助数詞が獲得されていく過 程を推測したが, さらに，この現象を引き起こすメカ ニズムは次のように想定されよう。Pinker ら (Pinker, 1991; Pinker \& Prince, 1988) は, 文法, とくに形態素の獲 得のメカニズムは, 自分の中で生成したルールを用い るものと経験から獲得した連合ネットワークによるも のという質的に異なる 2 つの下位システムに分解され るという「ハイブリット仮説」を提唱した。これら 2 つのシステムは並行して働き，先に答えの出た方で反 応が起こるという。自己生成したルールは類推によっ て般用されていくが, この般用の生起には語形の類似 性や経験頻度が絡んでいるだろうと推測している。

これと同様に，助数詞を獲得する過程でも，ともか く助数詞を付けて発話するという経験が最初に起こり, 5 歳後半ごろからは，付与ルールを生成するようにな ると，慣用かどうかは別にして，子どもなりに，付与 の仕方に一貫性が見られるようになる。それは自己生 成した暗黙のルールの当てはめを行うようになったた めであろう。この段階になると, 説明技能やディスコー スの理論の成立 (内田, 1990) に伴い, 説明を求められれ ばルールの使い分け基準を意識化し，説明することが できるようになる。

この段階になると, 子どもは自分が数えるときだけ でなく，他人の発話に敏感になる。自分が使う経験や 他人の発話を聞くという経験によって付与ルールが強 化されたり，ルールそのものを現実に合わせて修正し たり，付与の範囲を修正したりといったことが起こる ようになり，助数詞をマスターしていくのである。こ の修正のプロセスは般用現象によく現れている。

5 歳後半位からみられる助数詞の般用現象は語彙獲 得初期のもの (Okamoto, 1962) と似ているが, 語彙獲得 初期に比べ，修正や縮小の過程はきわめて短期間に達 成されるという特徵が認められる。これは, 幼児期後 期には，色，形，機能などへと注目する次元のシフト がきわめて柔軟かつスムーズに起こるため（内田, 1996), 付与基準を速やかに見つけることができるからではな いだろうか。従って他人が別の助数詞が付与されるの を 1 回あるいは数回聞くという経験だけで，助数詞付 与ルールの抽出や修正が速やかに起こるのであろう。

\section{（3） カテコリー形成と助数詞の獲得の関係}

本研究のデータからは, 当初の問題であった, 助数 詞の獲得される様相と獲得メカニズムの一端が明らか にされた。まず，幼児初期から，数えるときには，数 字の後に何か違うことばが付くという発話に曝されて いるうちに，どんな事物に対しても使用可能な一般的
な助数詞コやツを付けたり，ときに付けなかったりす る(仲, 1994) が，まだ付け方はでたらめで，身近な大人 の発話を真似している段階である。やがて，少数事例 の特性，たとえば，頭の場合は形状や大きさ(対象によっ ては「ロボットも自動車も人が運転するものだから 1 台， 2 台っ て数える」(I. S., 5:10) などのプロトコルから推測されるように 機能のこともありうるだろう）という知覚的次元で比較対 照することを通して，カテゴリー特徵が認知されるよ うになる。このカテゴリーの認知がベースになってそ のカテゴリー特徴を共有する一連の対象に対して一貫 して特定の助数詞を付与するようになる。さらに助数 詞を使用したり，他人の発話を聞く経験を通して，力 テゴリー自体の認知もしっかりと構成されるようにな るのであろう。

これらは，当初に想定した関係を支持するものであ る。すなわち, 意味, 認知カテゴリー形成が先か言語 ラベル，あるいは文法的クラスの方が先か，というよ うな単純な連鎖ではなく，双方が循環的に強化しあう ような関係がつくられていき，最終的に，生成的な意 味ルールを獲得しながらも，非典型事例についての慣 用的な助数詞クラスを学び，生成的かつ社会, 文化的 な慣用に見合った助数詞の用法を学んでいくのであろ う。

（4）今後の課題 まず, 生物カテゴリー以外の助数詞 についても同様の手続によって，その獲得過程を詳細 に検討することが必要である。

また, 本研究は横断的実験データによって獲得過程 を見たが，少数例であっても縦断的な観察デー夕に よって，本研究の知見が追認されるかどうかも検討す る必要がある。

さらに，言語圏によっては，助数詞がない，または 少ない場合がある。また, 中国語, 韓国語, ベトナム 語などでは，助数詞によって指示するカテゴリーの範 囲や対象が異なっている (Erbaugh, 1987) ${ }^{9}$ 。今後, これ ら助数詞の体系の異なる言語文化圏間で助数詞獲得過 程のデータを比較し，よりきめ細かな検討を行うこと によって, 文法と意味獲得, 言語と認知の関係の詳細 が明らかになることが期待される。

\section{引用文献}

Bowerman, M. 1982 Starting to talk worse :

\footnotetext{
たとえば, 中国語の条(tiao)は川, 道, 魚, 蛇, ミーアキャッ トやダックスフントを数えるのに使うが, これは曲線を描く長 いものという知覚的類似性と動きという特性を基礎にカテゴ リーを形成している。
} 
Clues to language acquisition from children's late errors. In S. Strauss, (Ed.), U-shaped behavioral growth. New York : Academic Press.

Carpenter, K. 1991 Later rather than sooner : Extralinguistic categories in the acquisition of Thai classifiers. Journal of Child Language, 18, 93-113.

Clark 1991 Aquisitional principles in lexical development. In S.A. Gelman, \& J.P. Byrnes(Eds.), Perspectives on language \& thought : Interelations of development. Cambridge : Cambridge University Press.

Denny, P. 1979 Semantic analysis of selected Japanese classifiers for unit. Linguistics, 17, $317-335$.

Downing, P. 1984 Japanese numerical classifiers : A semantic, syntactic, and function Profile. Unpublished doctral dessertation, University of California, Berkeley.

Erbaugh, M.S. 1987 Taking stock : The development of Chinese noun classifiers historically and in young children. In C. Craig (Ed.) Noun clauses and categorization. Amsterdam : John Benjamins.

Fisher, C., Hall, D.G., \& Gleitman, L. 1994 When it is better to receive than to give : Syntactic and conceptual constraints on vocabulary growth. Lingua, 92, 333-375.

Gathercole, V. 1985 'He has too much hard questions' : Acquisition of the linguistic count-mass distinction much and many. Journal of Child Language, 12, 395-415.

稲垣佳代子 1995 幼児の素朴生物学の獲得をめぐる 研究の 10 年 児童心理学の進歩 1995 年版, 235 - 258, 金子書房

Inagaki, K., \& Hatano, G. 1987 Young children's spontaneous personification as analogy. Child Development, 58, 1013-1020.

岩淵悦太郎・村石昭三 1976 『幼児の用語』日本

\section{放送出版協会}

Lakoff 1987 Women, fire dangerous things : What categries reveal about the mind. Chicago : Chicago University Press.

Matsumoto, Y. 1987 Order of aquisition in the lexicon : Implications from Japanese numerical classifiers. In K.E. Nelson, \& A. van Kleeck(Eds.), Children's Language, Vol.6, Hillsdale NJ : Lawrence Erlbaum.

Matsmoto, Y. 1993 Japanese numerical classifiers : a study of semantic categories and lexical organization. Linguistics, 31, 667 -713 .

仲真紀子 19942 歳児の日常生活にみられる助数詞 の使用 日本教育心理学会第 36 回総会発表論文 集, 67 .

Okamoto, N. 1962 Verbalization process in infancy ( I ). Psychologia, 5, 32-40.

Pinker, S. 1991 Rules of language. Science, 253, 530-535.

Pinker, S., \& Prince, A. 1988 On language and connectionism : Analysis of a parallesdistributed processing model of language acquisition. Cognition, 23, 79-193.

Soja, N., Carey, S., \& Spelki, E. 1991 Ontological categories guide young children's inductions of word meaning : Object terms and substance terms. Cognition, 38, 179-211.

内田伸子 1990 子どもの文章一書くこと・考えるこ と 東京大学出版会

内田伸子 1996 子どもの語意についての理論一語意 獲得初期における知覚的類似性の役割一お茶の 水女子大学人文科学紀要, 第 49 巻, 131-156.

$$
\text { 付 記 }
$$

実験に協力してくださった, 音羽幼稚園, 小日向保 育園, お茶の水女子大学附属幼稚園の園児の皆椂に感 謝いたします。

(1995.9.8 受稿, '96.1.11 受理) 